\title{
Mixed epithelial and stromal tumor in a young male case with hydronephrotic nonfunctional kidney: Comparison with literature findings
}

\author{
Hidronefrotik fonksiyon göstermeyen böbrekli genç erkek olguda mikst epitelyal stromal \\ tümör: Literatür bulguları ile karșılaștırma
}

\author{
Zeynep Sezal', Büșra Coșanay Tekden', Cevper Ersöz², Ganime Çoban'1 \\ 1 Bezmialem Vakıf University, Faculty of Medicine, Department of Pathology, Istanbul, Turkey \\ 2 Bezmialem Vakıf University, Faculty of Medicine, Department of Urology, Istanbul, Turkey
}

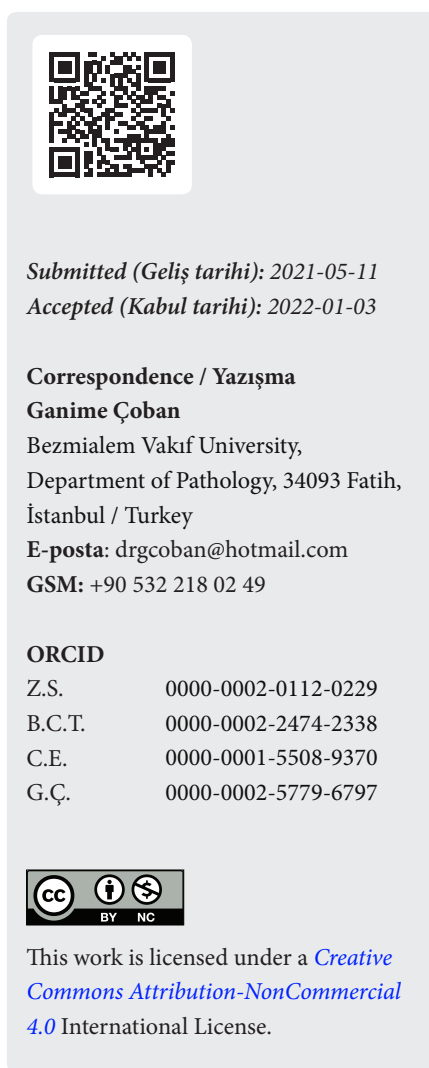

\section{Özet}

Mikst epiteliyal stromal tümör (MEST) ailesi, kistik komponenti baskın olan erişkin kistik nefroma ve solid komponent baskın MEST'ten oluşmaktadır. MEST, epitelyal ve stromal komponente sahip böbreğin nadir görülen benign, bifazik tümörüdür. Karın ağrısı ile başvuran 24 yaşında erkek olgunun tetkiklerinde grade 4 hidronefroz saptandi. Nefrektomi piyesinin mikroskobik incelemesinde, ovaryan stroma içerisinde değişken çaplarda küboidal epitel ile döşeli tubul yapıları mevcuttu. Olguya, morfolojik ve immunohistokimyasal bulgular ile MEST tanısı verildi. Genç erkeklerde sınırlı sayıda saptanan ve daha önce fonksiyon göstermeyen böbrek ile birlikteliği bildirilmeyen MEST tanısı verdiğimiz olgumuzun klinik ve histopatolojik özelliklerini literatür verileri ile karşılaştırmayı amaçladık.

Anahtar Kelimeler: Mikst epitelyal stromal tümör, böbrek, erkek.

\section{Abstract}

The mixed epithelial and stromal tumor (MEST) family is comprised of adult cystic nephroma with a dominant cystic component and MEST with a dominant solid component. MEST is the rarely observed benign, biphasic tumor of the kidney with a mixed epithelial and stromal component. In the examinations of a 24-yearold male patient who presented with abdominal pain, grade-4 hydronephrosis was detected. In the microscopic examination of his nephrectomy specimen, there were tubular structures with cuboidal epithelium in different diameters within the ovarian stroma. The patient was diagnosed with MEST via morphological and immunohistochemical findings. We aimed at comparing the clinical and histopathological characteristics of our case, which we diagnosed with MEST, which is encountered in limited numbers in young men and has never been reported together with a nonfunctional kidney before, to the literature data.

Keywords: Mixed epithelial and stromal tumor, nonfunctional kidney, male.

Cite As: Sezal Z, Tekden BC, Ersöz C, Çoban G. Mixed epithelial and stromal tumor in a young male case with hydronephrotic nonfunctional kidney: Comparison with literature findings. New J Urol. 2022; 17(1):52-57. DOI: 10.33719/yud.2022;17-1-936184 


\section{INTRODUCTION}

The mixed epithelial and stromal tumor (MEST) family is comprised of the adult cystic nephroma and mixed epithelial and stromal tumor. Adult cystic nephroma (ACN) had been classified together with pediatric cystic nephroma, independently from MEST, before (1). Later, ACN was included in the MEST family through clinical and genetic findings. MEST was first defined by Michal and Syrucek in 1998 and named as renal pelvis hamartoma, adult mesoblastic nephroma, cystic nephroma, mature nephroblastic tumor, or cystic partially differentiated nephroblastoma, respectively (2). ACN and MEST are benign kidney tumors with similar clinical, morphological, and immunohistochemical characteristics (1). The major morphological difference between the two groups is that cystic nephroma has a structure consisting of thin-walled cysts. On the contrary, MEST has cysts with thicker walls and solid areas. Ovary-like stroma is an important finding for MEST (3).

The mixed epithelial and stromal tumor mostly appears in perimenopausal women. The most common localization area is the pelvis; however, it can also be seen in the renal cortex (3). Macroscopically, it is a well-bordered tumor with a solid and cystic component, often growing towards the pelvis (4). Microscopically, hypocellular fibrous stroma and cellular spindle cell stroma are the most common types of stroma. It contains cystic structures in different diameters within the stroma. The cyst epithelium is cuboidal and likely to have the appearance of a tack (5). Immunohistochemically, stromal cells express the smooth muscle markers, Estrogen, and Progesterone while the epithelial component expresses GATA3 and PAX 8 (4). 22 cases have been reported in male patients, so far. This paper presents the MEST case detected incidentally with localization in the nonfunctional kidney in a young male case in company with clinical and pathological findings.

\section{CASE REPORT}

Our male case was 24 years old and presented to our hospital with abdominal pain. No characteristics were found in his laboratory examination. The patient did not have any comorbidity or family history, and grade- 4 hydronephrosis was observed in the left kidney in abdominal US examination; the renal pelvis diameter was measured as $16 \mathrm{~mm}$, which was considered stricture in the ureteropelvic junction. Clear findings conforming to hydronephrosis were found in the left kidney in the static kidney scintigraphy. Activity involvement had decreased in favor of the parenchymal injury in the kidney parenchyma. In the dynamic kidney scintigraphy, the size of the left kidney was increased, and there were blood-filling, concentration, and severe reduction expression functions. The patient underwent a left nephrectomy with a pre-diagnosis of an atrophic kidney.

In the macroscopic evaluation of the nephrectomy specimen, the pelvis and calyces had expanded. In the area, rim-shaped residual kidney parenchyma was observed. No solid focal points were observed in the pelvis, which had a cystic expanded appearance (Figure $1)$.

In the samples of the cystic areas, a $1.2 \mathrm{~cm}$ irregular tumor focus was observed in the pelvis. The tumor contained ductus structures in different diameters in the microscopic sections (Figure 2A). The ductus is lined with a single row of cuboidal epithelium and has nuclei with a tack appearance (Figure 2B). In the epithelium, subnuclear vacuolization was seen locally (Figure 2C). The presence of dystrophic calcification in the tumor attracted attention (Figure 2D). In the areas around the tumor, sclerotic glomeruli, atrophy in tubules, fibrosis in the interstitium, and slight mononuclear inflammatory cell infiltration were observed.

Strong staining was obtained with Estrogen (ER), progesterone (PR), Actin, and negative staining with CD10 in stromal cells in immunohistochemical studies on the tumor. In epithelial cells, on the other hand, strong staining was observed with PAX8 and GATA3 (Figure 3).

Based on the present findings, the patient was diagnosed with a mixed epithelial-stromal tumor. It was explained to the patient that studies such as mRNA gene expression profiles, Insulin-like growth factor 2 , Carbonic anhydrase 2 gene, and translocation $\mathrm{t}(1 ; 19)$ could be done. 


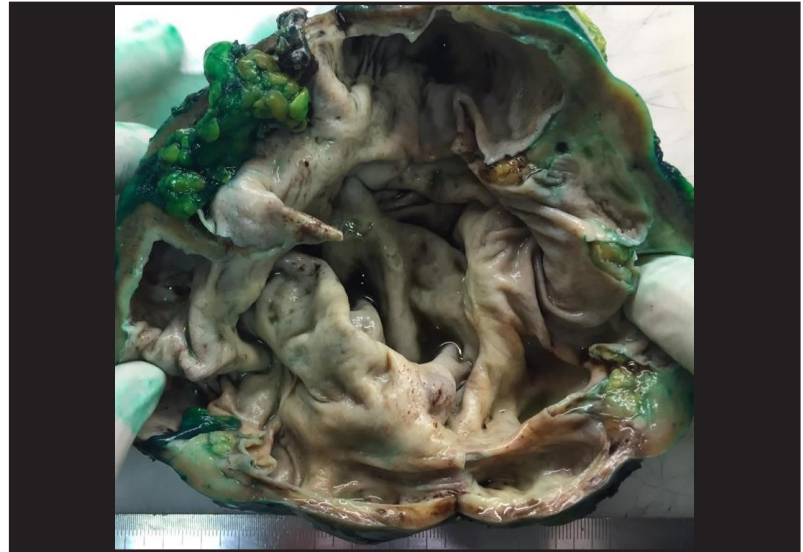

Figure 1. Gross appearance of the kidney

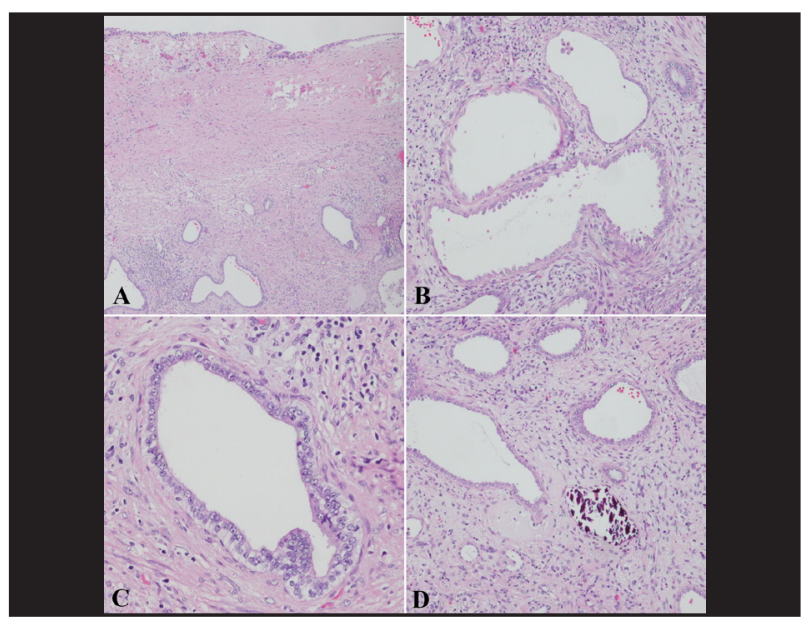

Figure 2. Ductus structure of different diameters in the pelvis (A, $H \& E x 40)$, ductus lined with cuboidal epithelium (B, H\&Ex100), subnuclear vacuolization of the epithelium (C, H\&Ex200), calcification in the tumor (D, H\&Ex100)

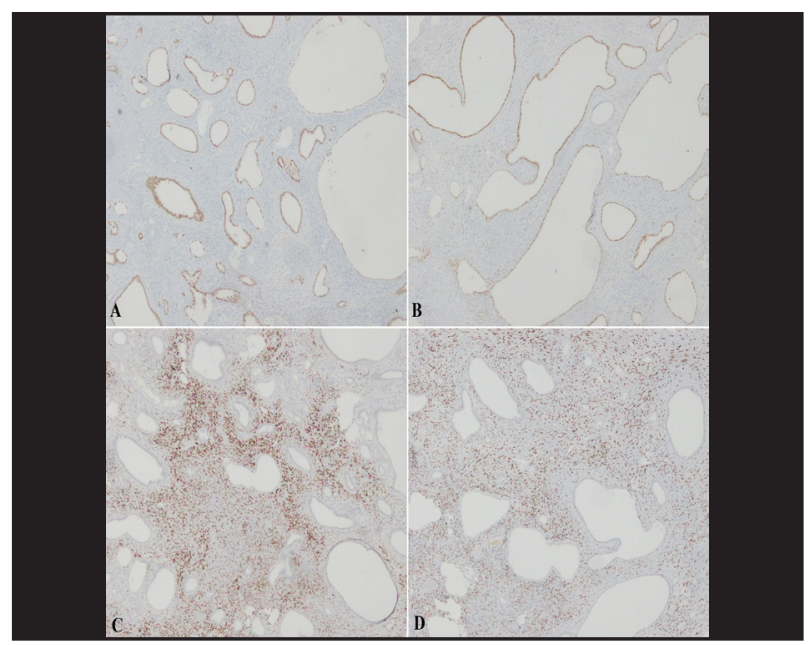

Figure 3. Positive staining with PAX8 and GATA3 in the epithelial component $(\mathrm{A}, \mathrm{B}, \mathrm{x} 100)$, positive staining with Estrogen and Progesterone in tumor stroma $(\mathrm{C}, \mathrm{D}, \mathrm{x} 100)$

\section{DISCUSSION}

Mixed epithelial and stromal tumors are rare benign, biphasic tumors. They are generally seen in perimenopausal women (3). Male cases are often in advanced ages and receive hormonotherapy (6). The number of cases reported in young men is limited in the literature. Most cases are incidentally detected, and dysuria, hematuria, and abdominal pain may be observed. Although they are well-bordered, solid, and cystic masses, the tumor in our case was irregular. They are often protruded to the renal pelvis. Histologically, they consist of stromal and epithelial elements. Hypocellular fibrous stroma and cellular spindle cell stroma are the most common types of stroma. Another common stroma type is the ovary-like stroma. It is a prevalent change, smooth muscle differentiation. In the female and male cases reported, there was no clear difference between the stromas $(4,5)$. Edematous fibrous stroma and fat tissue are other types of stroma $(3,5)$.

Moreover, calcification, ossification, chronic inflammation, and even necrosis can be observed. The epithelial component may have an appearance of branching tubules, which have tightly come together. The epithelium is cuboidal in those with a small tubular appearance. They may contain eosinophilic material resembling thyroid follicles. Complex papillary structures and a tack appearance are the other findings. Our case shows that there can be focal subnuclear vacuolization and oxyphilic cytoplasm. Immunohistopathologically, the stromal component is stained positively with the smooth muscle markers (smooth muscle actin, desmin, caldesmon), estrogen, progesterone, and CD10, and the epithelial component is stained positively with PAX8 and GATA3 (4).

In our literature review, we observed that 15 more male cases and 7 male cases reported by Anna et al. (4) were diagnosed with MEST. No findings could be reached about the seven cases. The average age of diagnosis of the fifteen cases was 42.4 (12-71) years. Two cases had abdominal pain, and 6 had hematuria and dysuria $(7-11,12)$. In six cases, tumors were detected incidentally $(2,6,13,16,17)$. There were 8 cases with localization in the right kidney and 4 cases with localization in the left kidney. The tumor diameter of these 


\begin{tabular}{|c|c|c|c|c|c|c|c|c|c|c|c|c|c|c|c|c|}
\hline 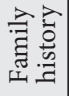 & \& & \& & \& & $\stackrel{\circ}{z}$ & $\stackrel{\circ}{z}$ & 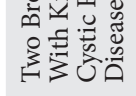 & z̊ & $\stackrel{\circ}{z}$ & $\stackrel{\circ}{z}$ & 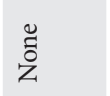 & 芩 & $\stackrel{\circ}{z}$ & $\stackrel{\circ}{z}$ & $\stackrel{\circ}{z}$ & $\stackrel{\circ}{z}$ & ̊ \\
\hline 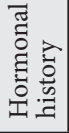 & 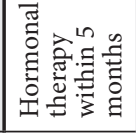 & $\begin{array}{l}\text { I } \\
\check{z}\end{array}$ & 气̆ & $\begin{array}{l}\tilde{\Xi} \\
\check{z}\end{array}$ & 气̆ & & ' & 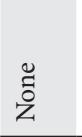 & \& & 亏̆ & 芩 & 亏̆ & $\stackrel{8}{9}$ & 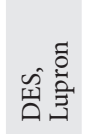 & g & ̊ \\
\hline 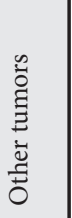 & 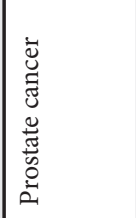 & 芩 & 亏ั̆ & 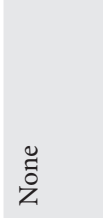 & 芩 & 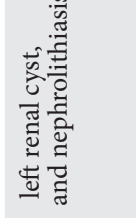 & \& & 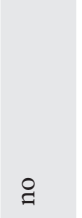 & : & 竞离 & \& & & 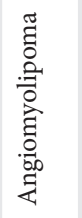 & 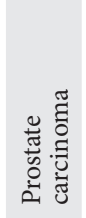 & $\stackrel{̊}{\nexists}$ & $\stackrel{9}{ }$ \\
\hline 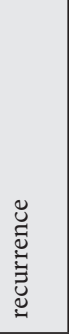 & 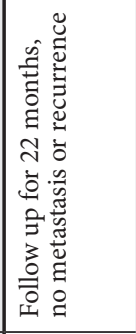 & 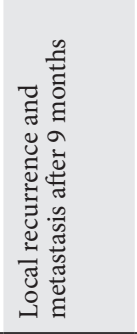 & 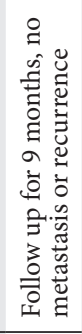 & 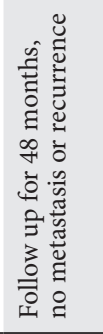 & 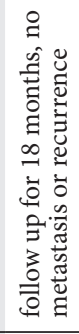 & 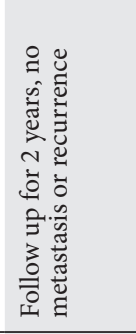 & $\stackrel{8}{\not}$ & 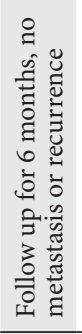 & 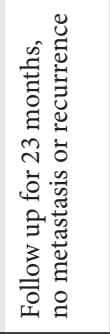 & & 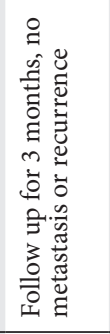 & 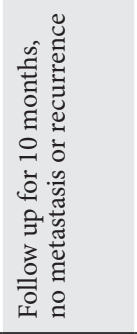 & 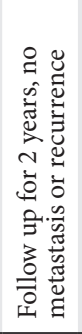 & & 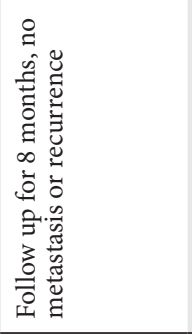 & 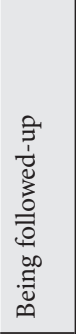 \\
\hline 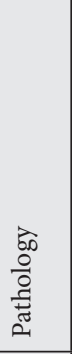 & 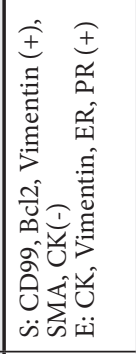 & 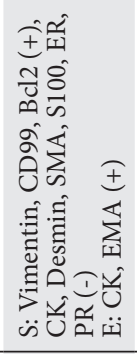 & 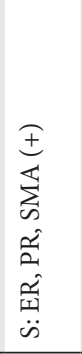 & 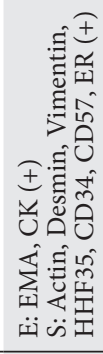 & 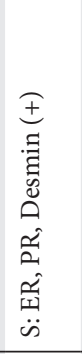 & & 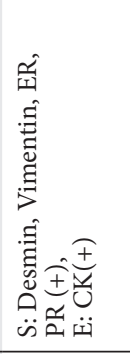 & 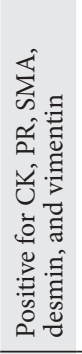 & 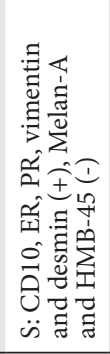 & 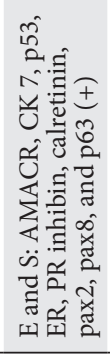 & 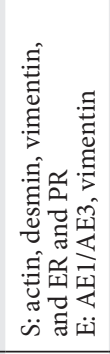 & 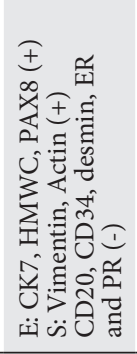 & & & 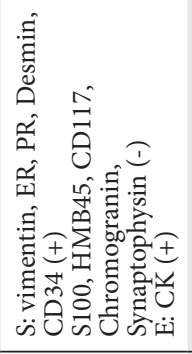 & 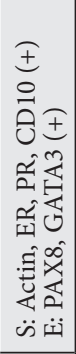 \\
\hline $\begin{array}{l}\widehat{\bar{\varpi}} \\
\vdots \\
\vdots\end{array}$ & 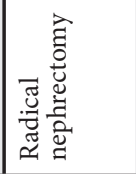 & 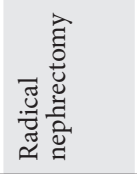 & 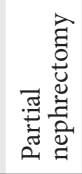 & 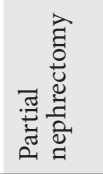 & 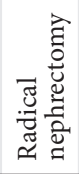 & 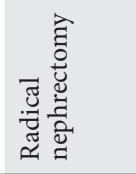 & 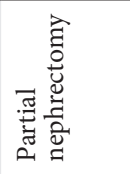 & 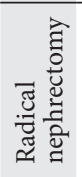 & 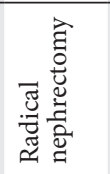 & 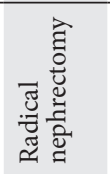 & 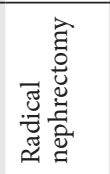 & 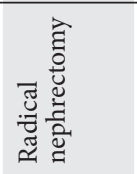 & 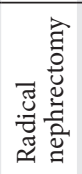 & & 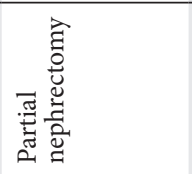 & 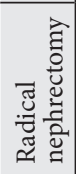 \\
\hline 颉 & $\begin{array}{l}E \\
5 \\
n \\
n \\
n\end{array}$ & 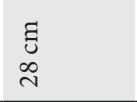 & $\begin{array}{l}\Xi \\
\text { N }\end{array}$ & $\begin{array}{c}\Xi \\
\text { ڤ }\end{array}$ & $\underset{\Xi}{\Xi}$ & $\begin{array}{l}\Xi \\
\tilde{n} \\
\delta\end{array}$ & $\overleftrightarrow{Z}$ & , & , & $\begin{array}{l}\Xi \\
\stackrel{0}{\circ}\end{array}$ & 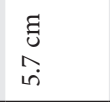 & $\begin{array}{l}\Xi \\
\vdots \\
6\end{array}$ & $\stackrel{\Xi}{\Xi}$ & $\stackrel{\text { 를 }}{=}$ g & $\underset{H}{\tilde{H}}$ & 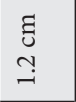 \\
\hline 芯 & 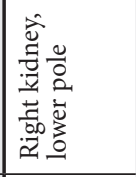 & 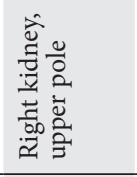 & 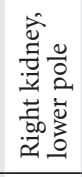 & 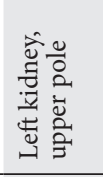 & 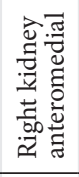 & 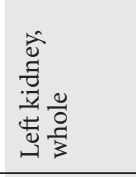 & 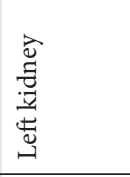 & , & , & 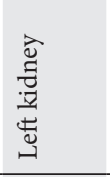 & 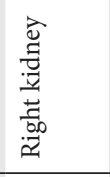 & 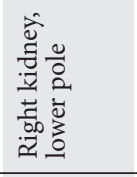 & 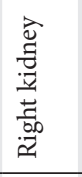 & & 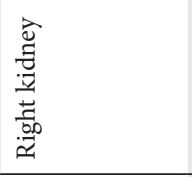 & 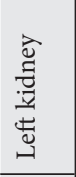 \\
\hline 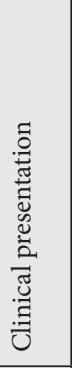 & 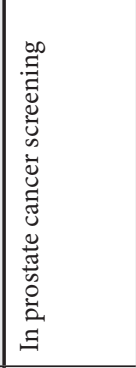 & 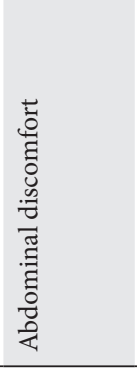 & 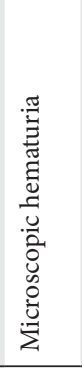 & 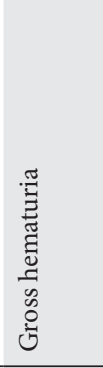 & 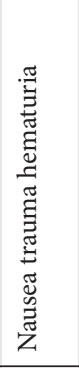 & 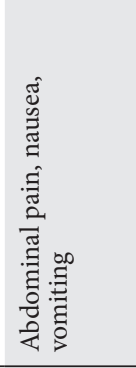 & $\frac{\mathbb{Z}}{\mathrm{Z}}$ & 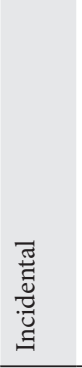 & 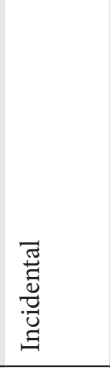 & 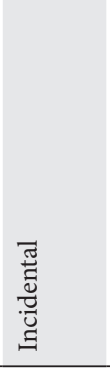 & 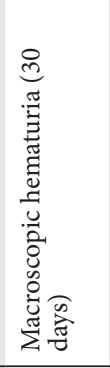 & 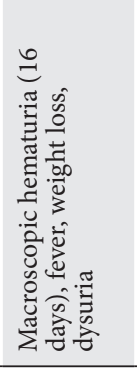 & 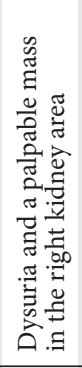 & 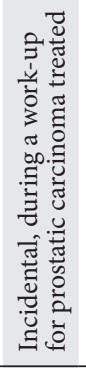 & 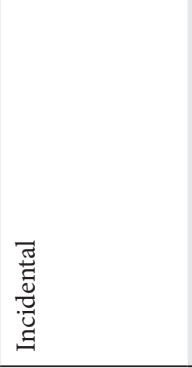 & 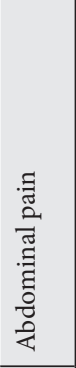 \\
\hline 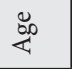 & 6 & 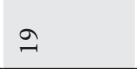 & $\exists$ & $\simeq$ & $\exists$ & 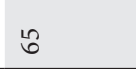 & 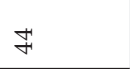 & 8 & $\stackrel{\infty}{i n}$ & $\infty$ & $\stackrel{\sim}{\sim}$ & $F$ & $\stackrel{0}{\sim}$ & $\pi$ & $\stackrel{\infty}{i n}$ & $\stackrel{\sim}{\sim}$ \\
\hline $\begin{array}{l}\mathscr{\mathscr { J }} \\
\tilde{J}\end{array}$ & 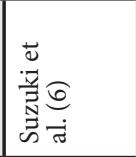 & 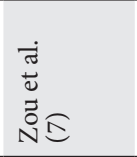 & 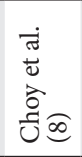 & 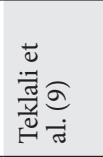 & 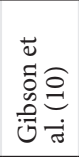 & 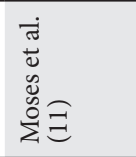 & ค.气 & 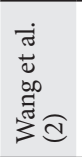 & 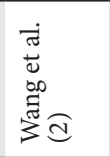 & 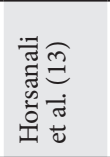 & 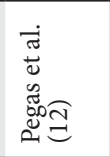 & 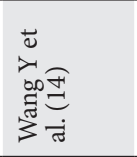 & 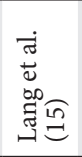 & 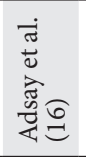 & 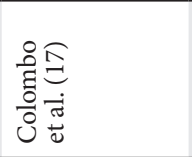 & 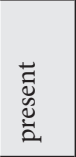 \\
\hline
\end{tabular}


15 cases was $10.3 \mathrm{~cm}$. As the operational procedure, 11 cases underwent nephrectomy and 4 partial nephrectomies. Only in 1 case reported by Zou et al. (7), out of the cases followed up for recurrence and metastasis, local recurrence and metastasis were found after 9 months. When we looked at their backgrounds, Suzuki et al. (6) and Adsay et al. (16) reported 2 cases in which hormone was used due to prostate cancer. Moses et al. (11) reported a case with a family history, and two brothers of the case also had cystic renal disease (Table 1). All the cases had similar histopathological and immunohistochemical findings.

Our case is young and male contrary to the expectations in MESTs. The tumor was detected incidentally in a nephrectomy performed for hydronephrosis. Because of these rare findings, we believe that our case report will contribute to the literature.

\section{Conflict of Interest}

All authors declared that there is no conflict of interest.

\section{Financial Disclosure}

The authors declared that this study has received no financial support.

\section{Author Contributions}

Conception and design; ZS, BCT, CE, GÇ, Data acquisition; BCT, Data analysis and interpretation; ZS, BCT, GÇ, Drafting the manuscript; ZS, GÇ, Critical revision of the manuscript for scientific and factual content; CE, GÇ, Statistical analysis; CE, GÇ, Supervision; CE.

\section{REFERENCES}

1. Michal M, Amin M.B, Delahunt B, Hes O, Oliva E. Mixed epithelial and stromal tumour family International Agency for Research on Cancer (IARC) Press, Lyon 2016; p. 70-71.

2. Wang C, Lin $\mathrm{Y}$, Xiang H, et al. Mixed epithelial and stromal tumor of the kidney: report of eight cases and literature review . World Journal of Surgical Oncology 2013;11:207

3. Jevremovic D, Lager D, Lewin M. Cystic nephroma (multilocular cyst) and mixed epithelial and stromal tumor of the kidney: a spectrum of the same entity? USA: Annals of Diagnostic Pathology. 2006;10; 77- 82.
4. Calio A, Eble J, Grignon D, Delahunt B. Mixed Epithelial and Stromal Tumor of the Kidney A Clinicopathologic Study of 53 Cases Am J Surg Pathol 2016;40:1538-1549.

5. Turbiner J, Amin M, Humphrey P, et al. Cystic Nephroma and Mixed Epithelial and Stromal Tumor of Kidney: A Detailed Clinicopathologic Analysis of 34 Cases and Proposal for Renal Epithelial and Stromal Tumor (REST) as a Unifying Term. Am J Surg Pathol 2007;31:489-500.

6. Suzuki T, Hiragata S, Hosaka K, et al. Malignant mixed epithelial and stromal tumor of the kidney: report of the first male case. Int J Urol. 2013; 20(4): 448-50.

7. Zou L, Zhang X, Xiang H. Malignant mixed epithelial and stromal tumor of the kidney: the second male case and review of literature. Int J Clin Exp Pathol. 2014; 7(5): 2658-63.

8. Choy B, Gordetsky J, Varghese M, et al. Mixed Epithelial and Stromal Tumor of the Kidney in a 14-Year-Old Boy Urol Int 2012;88:247-248.

9. Hara N, Kawaguchi M, Murayama S, et al. Mixed epithelial and stromal renal tumour in a 12-year-old boy. Pathology International 2005; 55: 670-676.

10. Gibson E, Batra N, Gordetsky J, et al. Case - Mixed epithelial and stromal tumours: A rare pediatric renal tumour. Can Urol Assoc J. 2018;24; Epub ahead of print.

11. Moses K, Oliva I, Osunkoya A, et al. An Unusual Presentation of a Mixed Epithelial and Stromal Tumor in an Elderly Male. Atlanta: The Scientific World JOURNAL 2010;10:1810-1813.

12. Pêgas $\mathrm{K}$, Cambruzzi E, Furian R, et al. Renal mixed epithelial and stromal tumor: case report J. Bras. Patol. Med. Lab. 2015;51:39-43.

13. Horsanali M, Yilmaz Y, Ozer K, et al. Mixed Epithelial and Stromal Tumor of the Kidney: Two Case Reports of a Rare Benign Kidney Tumor. Clinical Genitourinary Cancer, 2016;15:e55-e59.

14. Wang Y, Yuan J, Wang J, et al. Mixed epithelial and stromal tumor of the kidney: report of a rare case and review of literature. Int J Clin Exp Pathol 2015;8:1177211775.

15. Lang N, Li J, Liu J, et al. Mixed Epithelial and Stromal Tumor of the Kidney: An Analysis of Multidetector Computed Tomography Manifestations and 
Clinicopathologic Findings J Comput Assist Tomogr 2010;34: 177-181.

16. N V Adsay , J N Eble, J R Srigley, et al. Mixed Epithelial and Stromal Tumor of the Kidney. Am J Surg Pathol 2000;24:958-70.

17. Colombo P, Naspro R, Vallieri L, et al. Non-HormoneInduced Mixed Epithelial and Stromal Tumor of Kidney in a Man: Description of a Rare Case. UROLOGY 2008;71: 168-168. 